\title{
The effectiveness of brain-based mathematics teaching on academic procrastination, comprehension, and learning rate of students with Attention Deficit Hyperactivity Disorder (ADHD)
}

\author{
Mohammad Jafar Doosti Deilami ${ }^{1}$, Hossein Abbasian ${ }^{1}$, Seyyed Ali Kazemipour ${ }^{1}$ \\ 1-Assistant Professor, Department of Mathematics and Statistics, Aliabad Katoul Branch, Islamic Azad University, \\ Aliabad Katoul, Iran. \\ Corresponding Author: Mohammad Jafar Doosti Deilami \\ E-mail: Doosti1361@gmail.com
}

Received: 17/10/2021

Accepted: 19/12/2021

\begin{abstract}
Introduction: Brain-based teaching is the purposeful application of brain function strategies for teaching that affect learning.

Aim: The study evaluated the effectiveness of brain-based mathematics teaching on academic procrastination, comprehension, and learning rate of students with Attention Deficit Hyperactivity disorder.

Method: This study was experimental with a pretest-posttest design and a control group. The population was students with Attention Deficit Hyperactivity disorder in Gorgan in 2021. Thirty people were randomly selected and grouped into two experimental $(\mathrm{N}=15)$ and control $(\mathrm{N}=15)$ groups. Data were collected based on the Academic Procrastination Scale (Solomon and Rothblum, 1984), a researcher-made comprehension test, and a timer, and the experimental group received brain-based teaching four times a week for eight sessions. Data were analyzed by multivariate analysis of covariance (MANCOVA) with SPSS software version 25.
\end{abstract}

Results: The results showed that mathematics education by brain-based method reduces academic procrastination $(\mathrm{P}<0.01, \mathrm{~F}=184.924)$; increased comprehension $(\mathrm{P}<0.01, \mathrm{~F}=80.504)$ and learning speed $(\mathrm{P}<0.01, \mathrm{~F}=165.559)$ in students with Attention Deficit Hyperactivity disorder.

Conclusion: Since brain-based math education affects academic procrastination, comprehension and learning speed of students with Attention Deficit Hyperactivity disorder, it is suggested that for the development of students with Attention Deficit Hyperactivity disorder, brain-based teaching should be adopted for normal classes and children with learning disabilities in curricula.

Keywords: Brain-based mathematics teaching, Academic procrastination, Comprehension, Learning rate, Attention Deficit Hyperactivity Disorder (ADHD)

\footnotetext{
How to cite this article: Doosti Deilami MJ, Abbasian H, Kazemipour SA. The effectiveness of brain-based mathematics teaching on academic procrastination, comprehension, and learning rate of students with Attention Deficit Hyperactivity Disorder (ADHD). Shenakht Journal of Psychology and Psychiatry. 2022; 8 (6): 125-137 .URL: http://shenakht.muk.ac.ir/article-1-1367-en.pdf
}

Copyright $\odot 2018$ the Author (s). Published by Kurdistan University of Medical Sciences. This is an open access article distributed under the terms of the Creative Commons Attribution-Non Commercial License 4.0 (CCBY-NC), where it is permissible to download, share, remix, transform, and buildup the work provided it is properly cited. The work cannot be used commercially without permission from the journal. 


\title{
اثربخشى آموزش رياضى به روش مغز محور بر اهمالكارى تحصيلى، درك مطلب و سرعت يادكيرى دانش آموزان مبتلا به اختلال نقص توجه / بيشفعالى مونى
}

\author{
محمد جعفر دوستى ديلمى'، حسين عباسيان'، سيد على كاظمى يور' \\ 1.استاديار، گروه رياضى و آمار، واحد على آباد كتول، دانشكاه آزاد اسلامى، على آباد كتول، ايران. \\ مولف مسئول: محمد جعفر دوستى ديلمى ايميل: Doosti1361 @
}

مقدمه: آموزش مبتنى بر مغز، مشاركت هدفمند راهبردهايى است كه در زمينه عملكرد مغز در متن آموزش اعمال مىشود و سبب اثر گذارى بر ياد گيرى مىشود.

هدف: يزوهش حاضر با هدف بررسى اثربخشى آموزش رياضى به روش مغز محور بر اهمال كارى تحصيلى، درك مطلب و سرعت

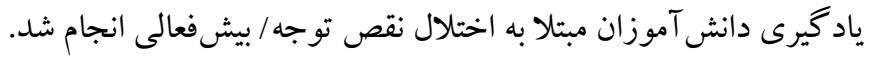

روش: اين يثوهش از نوع مطالعات آزمايشى با طرح بيش آزمون- بِ آزمون با كروه كنترل بود. جامعه آمارى يُوهش را دانش -

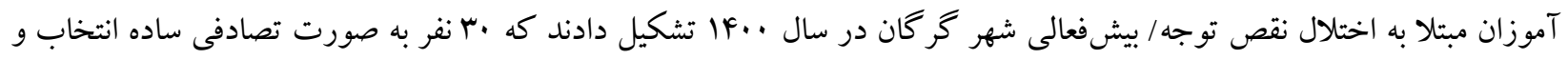
در دو گروه آزمايش (ها نفر ) و گواه (ها نفر ) جايكزين شدند. جمع آورى اطلاعات براساس مقياس اهمال كارى تحصيلى (سولومون و

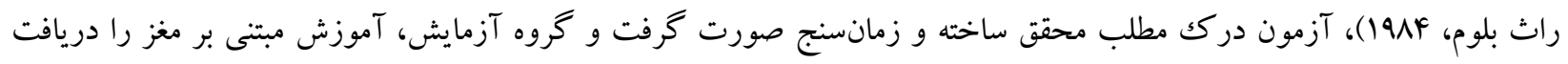
نمودند. دادهها از طريق آزمون كوواريانس جند متغيرى (مانكووا) با نرمافزار SPSS نسخه هץ تجزيه و تحليل شدند.

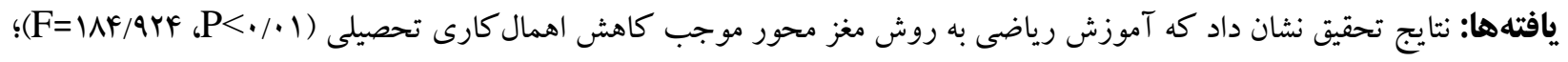

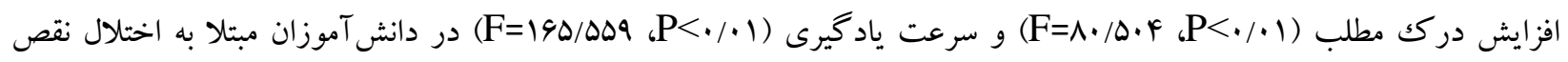
توجه / بيشفعالى مى شود.

نتيجه كيرى: از آنجايى كه آموزش رياضى به روش مغز محور بر اهمال كارى تحصيلى، درك مطلب و سرعت ياد گيرى دانش آموزان

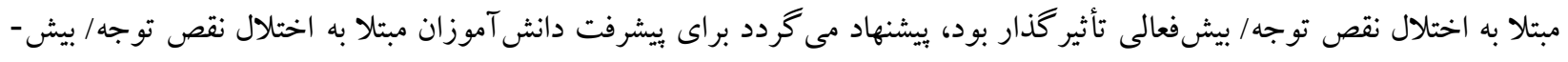

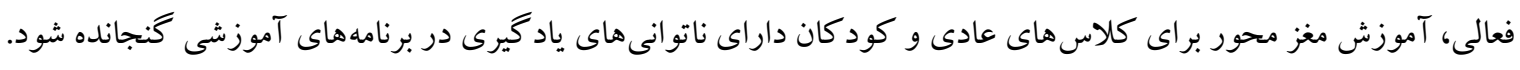
كليدوازهها: آموزش رياضى به روش مغز محور، اهمال كارى تحصيلى، درك مطلب، سرعت ياد گيرى، اختلال نقص توجه/ بيش- 
مثال، يكى از علائم بع توجهى به اين نكته اشاره مى كند مقدمه كه فرد "اغلب از انجام كارهايى كه نياز به تلاش ذهنى مداوم دارند، اجتناب مى كند، دوست ندارد يا تمايلى

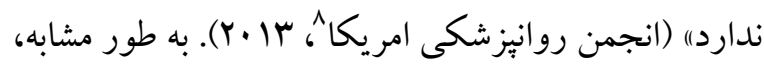

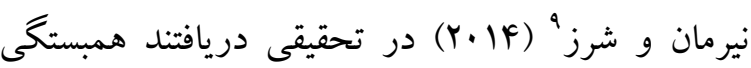
مثبتى بين علائم بى توجهى مربوط به اختلال نقص توجه/ بيشفعالى و اهمال كارى تحصيلى وجود دارد. نشانهاى رفتار اهمال كارى تحصيلى دانش آموزان عبارتند از: تمايل به تأخير در انجام تكاليف (اتلاف وقت)، تمايل به تجربه تأخير در صورت مشكل در انجام كارهاى ناخوشايند (اجتناب از كار) و تمايل به سرزنش ديخر درون دران براى اشتباهات خود (سرزنش كردن ديخران) (اكوستين و وينارسو، (Y.Y.Y). ظهور رفتار دانش آموز به شكل اهمالكارى در انجام تكليف داده شده، يكى از تأثيرات ناتوانى

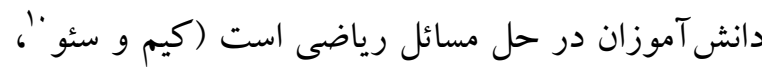

از سويى داشتن مهارتهاى دركك مطلب " در خواندن دروس من جمله رياضى بسيار مهم است. دركك مطلب لذت و اثربخشى خواندن را افزايش مىدهد و نه تنها از نظر تحصيلى بلكه حرفهاى و در زندگى شخصى فرد نيز

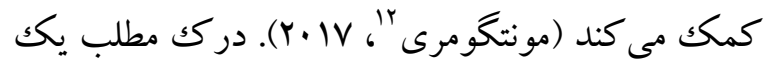
ساختار كلى است كه شامل يافتن عنوان مناسب، تعيين

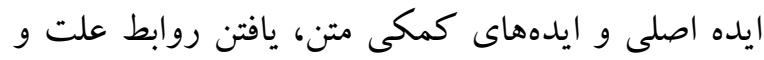
معلولى در متن و ييشبينى معانى كلمات مجهول در متن است (اوزتوركك، اكان و كايلان" تحقيقاتى انجام شده در اين رابطه نشان مىدهد كه دركى

8 - American Psychiatric Association

9 - Niermann HCM \& Scheres A

${ }^{10}$ - Kim \& Seo

11- Comprehension

${ }^{12}$ - Montgomery

${ }^{13}$ - Ozturk M, Akkan Y \& Kaplan A

1- Attention Deficit Hyperactivity Disorder (ADHD)

${ }^{2}$ - Arbel Y, Fialkoff C, Kerner A \& Kerner M

3 - Maria R \& Cornoldi C

4- Lowrie T \& Jorgensen R

5 - Ghazala N, Riffatun NA \& Hijab F

${ }^{6}$ - Academic procrastination

7- Agustin AR \& Winarso W 
مىتواند در روند يادگيرى بهينه شود (هاندايانى و

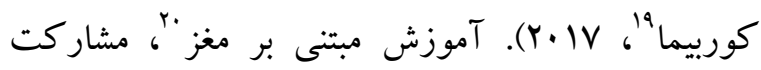
هدفمند راهبردهايى است كه در زمينه عملكرد مغز ما در متن آموزش اعمال مىشود. فعاليتهاى ياد گيرى (امغز محور) هر دو نيمكره مغز را به طور همزمان درگير مى - مونى كند، در نتيجه تجربههاى يادگيرى قوىتر، معنىدارتر و

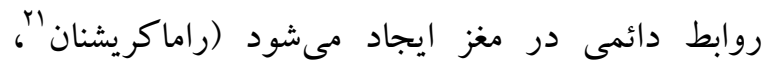

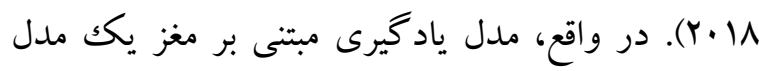
ياد گيرى تلاش محور است كه توانايى مغز دانش آموزان را تقويت مى كند. علاوه بر اين، محققان بر اين عقيدهاند كه اكر راهبردهاى آموزشى مغز محور براى آموزش اتخاذ شود، كود كان مبتلا به اختلال مبتلا به نقص توجه/ بيشفالى مى توانند از نظر تفكر متنى، استدلال خلاق، تفكر منطقى، ياد گيرى متوالى، دانش شهودى و يادگيرى بصيرت بهتر بهبود يابند كه در برابر فراموشى مقاوم هستند و اين به نتايج ياد گيرى شناختى و هيجانى بهتر در

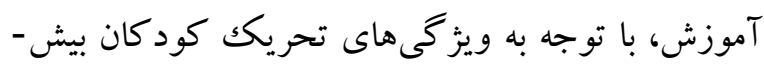
فعال در دوره ياد گيرى كمكك مى كند (ايانتويى،

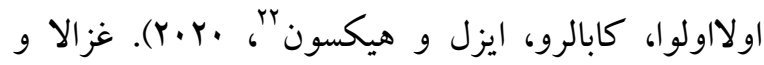
همكاران (Y. IV) در تحقيقى نشان داد كه گروه آزمايشى كه آموزش يادگيرى مغز محور دريافت كردند، نسبت به گروه گواه عملكرد رياضى بالاترى داشته است.

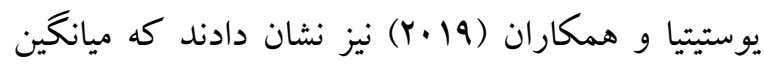
نمره مهارتهاى تفكر سطح بالاى دانش آموز در كلاس ياد گيرى مبتنى بر مغز بهتر از نمره ميانكين مهارت تفكر بهر

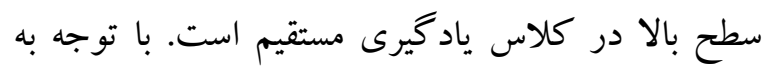

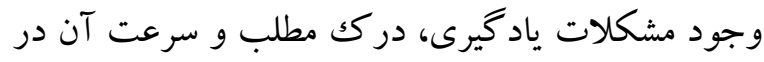

19- Handayani BS \& Corebima

${ }^{20}$ - Brain-based training

${ }^{21}$ - Ramakrishnan

${ }^{22}$ - Ayantoye, Olaoluwa , Caballero, Ezell \& Hixson
مطلب براى حل مسائل و بيشرفت در رياضى مهم است

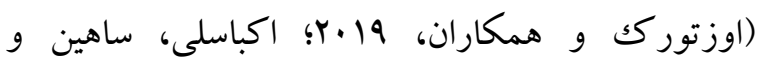

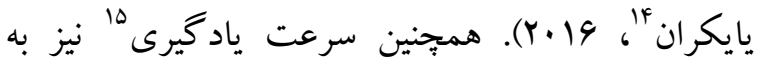
عنوان يكك ويز كى روانشناختى در دانش آموزان مىتواند تحت تأثير روش تدريس قرار گيرد (كرالدلى روسى

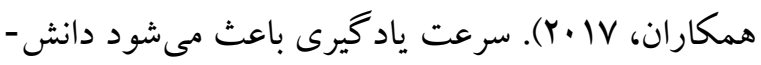
آموزان از زمانى كه در كلاس مى گذرانند بيشترين

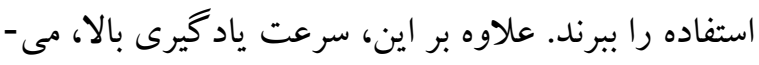
تواند دركك مطالب درسى را در همان مدت زمان و انكيزه و مشاركت دانش آموزان را در ياد گيرى افزايش

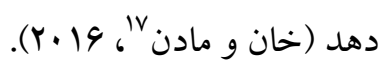
در بسيارى از مدارس، رياضيات در شرايط نامطلوب با روشهاى معمولى آموزش داده مىشود؛ به عبارت ديخر، روشى كه در حال حاضر در كلاس درس استفاده مىشود، به اهداف مناسب براى تدريس رياضى نرسيده

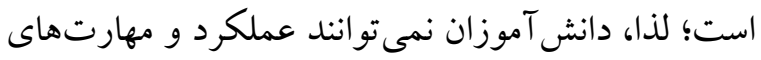
رياضى خود را توسعه دهند و عملكرد آنها نيز در اين زمينه ضعيف است (خان، Y| (Y). يكى از اين راهكارهاى مؤثر راهبرد يادگيرى (امغز محور") است كه رويكردى ابتكارى در آموزش و يادگيرى دروس مدرسه است. ياد گيرى مغز محور يك روش ياد گيرى است كه با نحوه طراحى طبيعى مغز هماهنگك است (يوستيتيا و همكاران، (Y.19). ياد گيرى مغز محور نتيجه درك نحوه ياد كيرى مغز و ارتباط آن با حوزه آموزش است. يادگيرى مغز

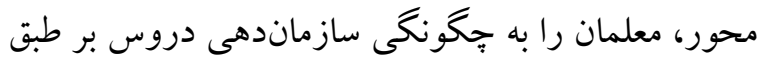
عملكرد ار گانيكك مغز آكاه مى كند و بر اين ايده تأكيد دارد كه هر قسمت از مغز عملكردهاى خاصى دارد كه

${ }^{14}$ - Akbasli S, Sahin M \& Yaykiran Z

15 - Learning speed

${ }^{16}$ - Geraldeli Rossi R

${ }^{17}$ - Khan AA \& Madden J

18 - "Brain-centered" learning 
يُزوهش حاضر، شامل دانش آموزان مقطع متوسطه مبتلا

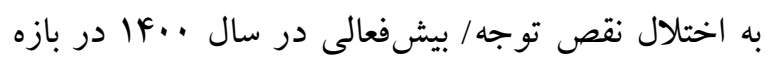
سنى rاتا ها سال شهر گر گان بودند، كه ·ب نفر از آنان به صورت داوطلبانه و در دسترس از بين مراجعه كنندكان

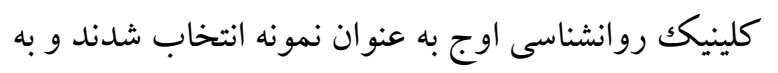
صورت تصادفى ساده در دو كروه آزمايش (هانفر) و

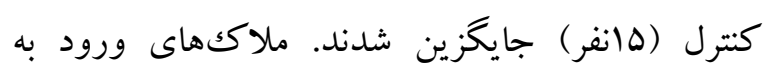
يثزوش شامل اعلام موافقت جهت شركت در بزوهش، دانش آموز داراى اختلال نقص توجه/ بيشفعالى، عدم ابتلا به بيمارىهاى جسمانى و ملاككهاى خروج شامل

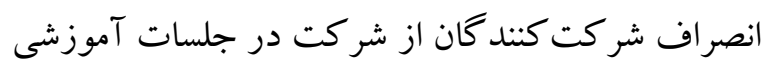
بود. بعد از انتخاب داوطلبانه افراد شركت كننده مرحله ييش آزمون اجرا شد. آموزشهاى لازم به كروه آزمايش داده شد و سبس، از هر دو گروه آزمايش و گتواه بس آزمون گرفته شد. جهت رعايت اخلاق بيزوهشى، براى والدين دانش آموزان جلسات توجيهى بر ززار

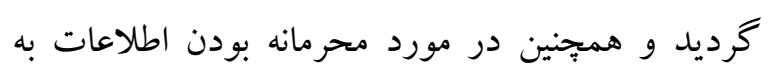
نمونه هاى بزوهش اطمينان داده شد. بعد از كسب مجوزهاى لازم و مراجعه به كلينيك روانشناسى اوج از بين دانش آموزانى كه ملاككهاى ورود در مورد آنها صدق مى كرد و نمرات بايينى در متغيرهاى تحقيق كسب كرده بودند، ·ب نفر به صورت تصادفى

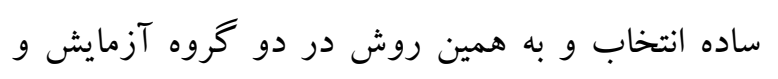

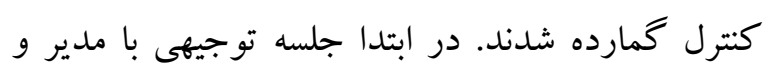
دبير رياضى در خصوص نحوه انجام مطالعه صورت گرفت و بِ از توجيه مديران مدارس و رضايت آكاهانه دانش آموزان هدف يزٔوهش و روش اجراى طرح ذكر

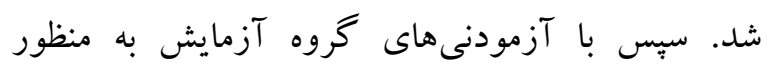
شركت در جلسات آموزش هماهنگىهاى لازم به عمل
دانش آموزان مبتلا به اختلال نقص توجه / بيشفعالى، لزوم به كارگيرى مداخلات آموزشى بر روى اين كودكان داراى ضرورت و اهميت دارد. آكاهى از اين كه مغز جِگونه ياد مى گيرد تأثير مهمى بر آموزش داشته باشد. بيشرفت دانش مغز به يُزوهشخران و مربيان كمكك مى كند

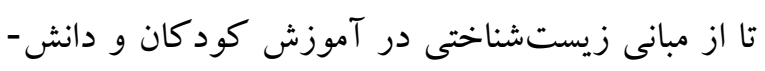
آموزان بهره گيرند. اكر بتوان از نحوه يادكيرى و بـ دريه

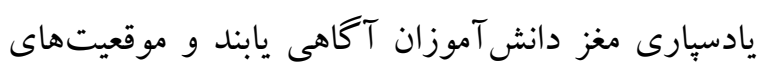

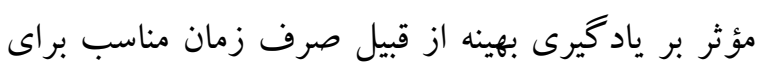

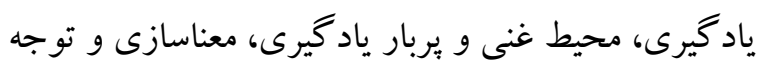
به هيجانات و نقش فعال دانش آموزان مبتلا به اختلال نقص توجه / بيشفعالى را در امر يادگيرى درس رياضى

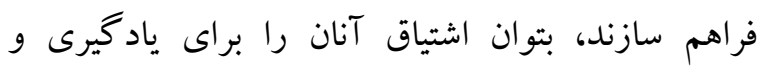
سرعت دركك مطلب افزايش داده و با حذف تهديد و اضطر اب بتوان ميزان اهمال كارى تحصيلى را كاهش داد.

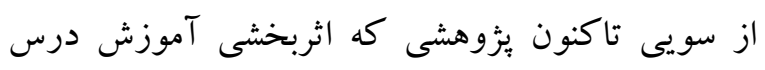
رياضى مغز محور را به طور همزمان بر متغيرهاى اهمالكارى تحصيلى، درك مطلب و سرعت ياد گيرى در بين دانش آموزان مبتلا به اختلال نقص توجه / بيش فعالى مورد بررسى قرار نداده است؛ لذا به دليل مشكلات تحصيلى به ويزه در دروس رياضى اين دانش آموزان، بثزوهش حاضر

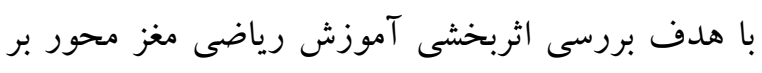
اهمال كارى تحصيلى، درك مطلب و سرعت ياد كيرى دانش آموزان داراى اختلال نقص توجه / بيشفعالى انجام

روش بثزوهش حاضر از نوع شبه آزمايشى با طرح

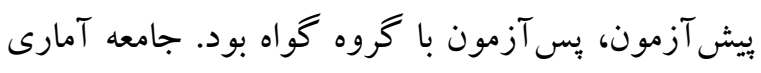




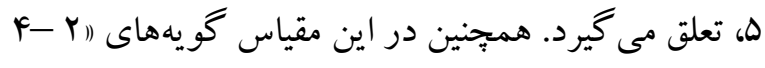
- 11-9معكوس نمره گذارى مىشوند. ايـن مقيـاس بـا برسشـنامه افسردگى بـك،، مقيـاس شناختهاى غيرمنطقى اليس، مقياس عزت نفس روزنبر گك و مقياس اجتناب روزانه همبستخگى معنادارى دارد كه نشان دهنده روايى مقياس است (سولومون و راث بلوم، IA1F). همجنين جو كار و

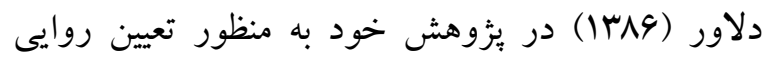
مقياس اهمال كارى تحصيلى از روش تحليل عاملى و همبستكى گويه با نمره كل استفاده كردهاند و بايايى آن براساس ضريب آلفاى كرونباخ برابر با 19/، و ورايى آن براساس آزمون كايزر-مير-اولكين برابر با MA/ · بدست

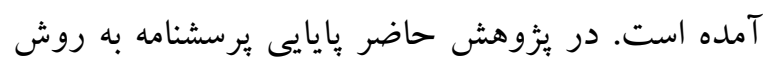
ضريب آلفاى كرونباخ سل/ • بدست آمد. آزمون دركى مطلب محقق ساخته: در اين يزٔوهش از يكك آزمون • اسؤالى تستى براى سنجش دركى مطلب و با توجه به مسائل رياضى استفاده شد. براى تهيه اين

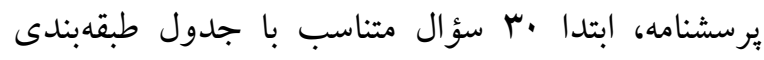
هدف هاى شناختى براساس محتواى متن مورد استفاده

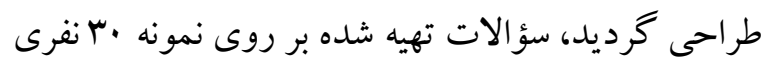
از دانش آموزان بعد از مطالعه متن، به صورت مقدماتى اجرا شد تا ويزگىهاى روانسنجى سؤالات استخراج

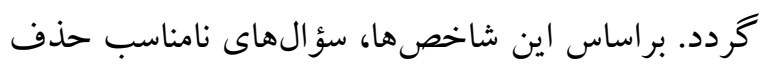
و فرم نهايى (• اسؤالى) آزمون دركك مطلب بدست آمد.

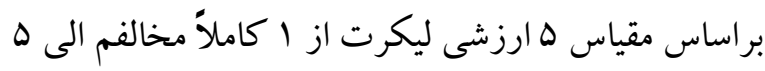
كاملاً مو افقم مورد سنجش قرار كرفته است. ميز ان بايايى اين ابزار برحسب روش آلفاى كرونباخ 194. بدست
آمد تا در \& جلسه آموزش به معلمان (طى F جلسه)،

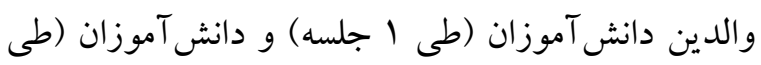
ا جلسه) شركت نمانيد. يس از آموزش از معلمان نيز

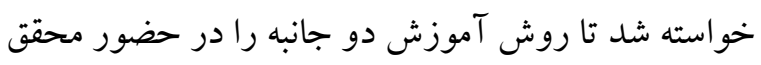
اجرا نمايند و در حين اجرا و بس از آن اشكالات آنها بـر طرف گرديد و دستورالعمل اجراى آموزش دوجانبه

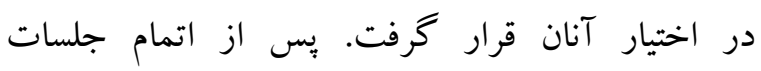
آزمودنى هاى هر دو گروه مجدداً از لحاظ متغير وابسته به عنوان بِ آزمون مورد بررسى قرار گرفتند. براى تحليل دادهها از آزمون آمارى تحليل كوواريانس و نرمافزار SPSS

ابزار مقياس اهمال كارى تحصيلى سولومون و راث بلوم" آمار"

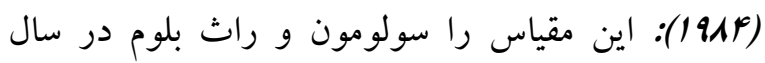
(I تهيه نمودند. اين مقياس را دهقانى (I IAYF) اولين بار در ايران بكار برده است. اين مقياس داراى TV ماده و ץ مؤلفه آماده شدن براى امتحانات (شامل N ماده)، آماده شدن براى تكاليف (شامل ل/ ماده) و آماده شدن براى مقالههاى يايانترم (شامل ^ ماده) است. در مؤلفه سوم، مادههاى مربوط به مقالهــاى بايان ترم، به صورت بهر تكاليف تحقيقى و يُوهشهاى كلاسى براى دانشآموزان در نظر كرفته شـد و اين كزينه براى ياسخ دهند كان به اين مقياس توضيح داده شد. نحوه بِاسخدهى به مادهها به اين صورت است كه باسخدهند كان ميزان

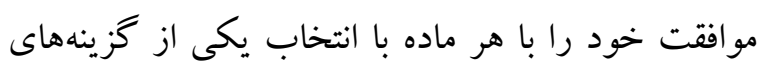

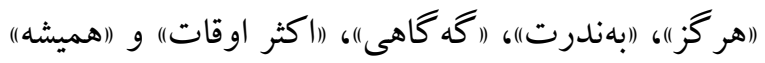
نشان مىدهند كه به گزينه (هر گز)" نمره اك (ابهندرت) نمره

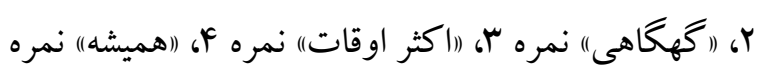

${ }^{23}$ - Solomon and Rothblum Academic Procrastination Scale 
(محيط غنى شده) "بوسترها، تصاوير، گگرافيك و جند رسانهاى مرتبط با موضوع نمايش داده شد و تصاوير كاريكاتور شده آويزان شد. اسلايدهاى موازى با محتوا در هر درس نمايش داده مىشود. جهت آماده سازى براى شروع درس مسائل يا حقايقى در زندكى روزمره مرتبط با مطالب مورد رياضى مورد مطالعه ارائه شد.

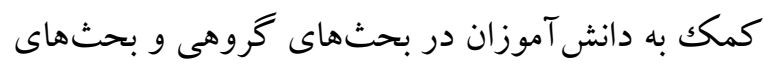
كلاسى و همجينين در زمان استراحت به دانش آموزان توصيه شد كه آب بنوشند. فرصتهاى همكارى و كار كروهى براى افزايش آكاهى هيجانى و آرامش فراهم

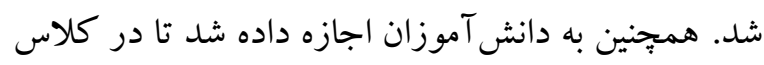
درس بجير خند و آزادانه بحث كنند و بارش فكرى كنند. همجنين به دانش آموزان كفته شد كه هر فردى در قبال خود مسئول است كه هم استرس را از بين ببرد و هم خود را به جالش بكشد. دانشآموزانى در طى دوره تشويق مىشدند كه نمونه مسائل رياضى خود را حل و مورد

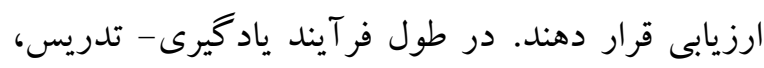
يك محيط كلاسى با "ايمنى فيزيولوزيكى" و "آرامش

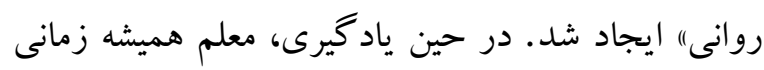
را در نظر مى گيرند تا به دانشآموزانى كه خواب آلود

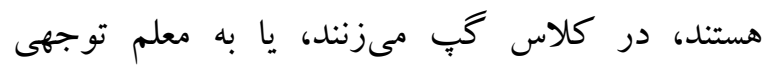
نمى كنند، آزمايش مغزى (غافلخيرى) به شكل جهالش ياسخكو باشند و به مسئله يّاسخ دهند. در قسمت سوم

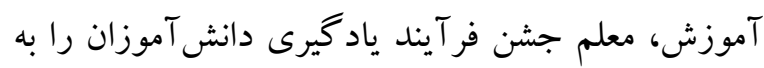

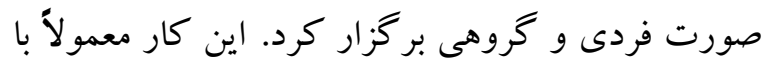
تشويق و هدايايى به دانش آموزانى كه در زمان ياد گيرى موفق به حساب مى آيند، انجام مىشود، هدف از اين كار، جلب توجه دانش آموزان به ياد گيرى فعالتر و با انكيزهتر از هميشه است. در انتهاى كلاس از دانش آموزان در
زمانسنج: در بثزوهش حاضر براى ثبت مدت زمان حل

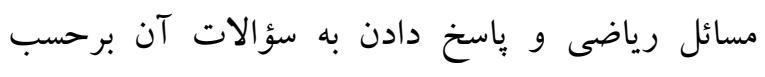
دقيقه، از ساعت كار كامييوترى استفاده شده تا بدين وسيله سرعت ياد گيرى آزمودنىها مشخص گردود. سرعت ياد كيرى مدت زمانى است كه دانش آموز صرف حل مسائل رياضى مى كند و ابزار سنجش آن زمانسنج برحسب دقيقه است (سيفى،

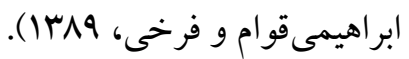

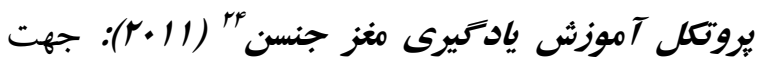
جمع آورى دادهها از يروتكل آموزش يادگيرى مغز

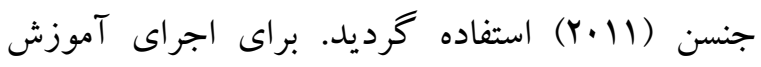
يادگيرى در قسمت اول، يزوهشكر در مدت دو ماه مباحث ياد گيرى مغز محور را كه عناوين آن عبارت بود مد مدرد از ساختار فيزيولوزيكى مغز، تأثير فشار روانى بر مغز و ياد گيرى، مؤلفها و اصول يادكيرى مغز محور و تأثير مؤلفههاى محيطى تأثير گذار بر مغز و ياد گيرى، به معلمان

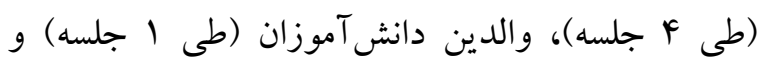
دانش آموزان (طى ا جلسه) آموزش داده شد. در قسمت دوم، معلمان در طول كلاس درس به مدت Y ماه از اصول ياد گيرى مغز محور براى آموزش رياضى به دانش آموزان استفاده نمودند. در اين بخش قبل از شروع كلاس دانش آموزان به تغذيه مغز، نوشيدن آب كافى، كشش لمش لمش

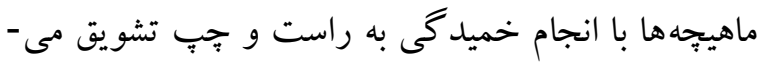
شوند. براى هشيارى آرام درس با موسيقى شروع شد. شرايط لازم براى ادراكك تحصيلى مثبت از خود ينداره براساس اصولى مانند "هر مغزى منحصر به فرد است و

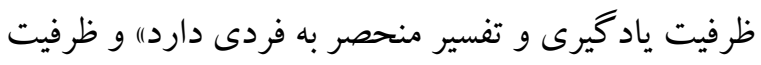
يادگيرى و تفسير منحصر به فردى دارد) فراهم شد. براى

${ }^{24}$ - Jensen brain learning training 
براساس يافتهاى حاصل از آمار توصيفى

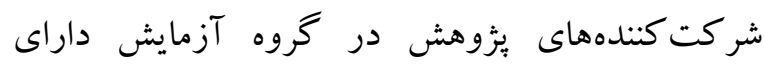

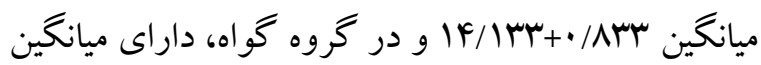
 توصيفى متغيرهاى اهمال كارى تحصيلى، درك مطلب و

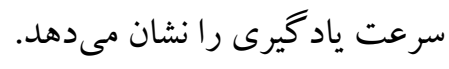

مورد آنجه امروز آموختهاند سؤال مىشود. در نهايت

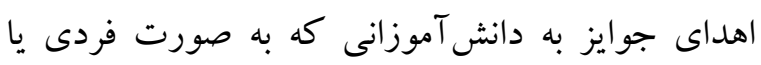
كروهى فعال هستند و تشويق دانش آموزان به ابراز هيجان براى موفقيت نيز از عوامل انكيزشى بوده است.

\begin{tabular}{|c|c|c|c|c|c|}
\hline \multicolumn{2}{|c|}{ يس آزمون } & \multicolumn{2}{|c|}{ يشي آزمون } & \multirow[t]{2}{*}{ كروه } & \multirow[t]{2}{*}{ متغير } \\
\hline انحراف معيار & ميانغين & انحراف معيار & ميانكين & & \\
\hline $9 / 1.4$ & $\Delta Q / \mu r \mu$ & $V / 9 \Delta$ & $V r / Y 94$ & آزمايش & اهمال كارى تحصيلى \\
\hline $91 \cdot v 9$ & VY/aTr & q/ard & Vr/Trr & كواه & \\
\hline r/94I & $14 / .99$ & $r / r q$. & $11 / \cdot \cdot$ & آزمايش & در كى مطلب \\
\hline 1/arr & $1 . / 499$ & r/9ar & $1.19 .$. & كواه & \\
\hline N/YFT & $r \cdot / r \mu r$ & $V / a \cdot V$ & FI/TrT & آزمايش & سرعت يادكيرى \\
\hline $9 / 99 \mathrm{~V}$ & $F r / F .$. & $\Lambda / r F V$ & Fr/9.. & كواه & \\
\hline
\end{tabular}

حالى است كه تغييرى براى گروه گواه، در مرحله يس آزمون ديده نمى

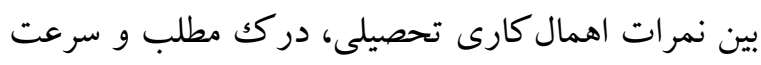

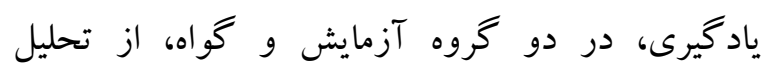
كواريانس جند متغيره در جدول r استفاده شد.
نتايج جدول انشان مىدهد كه براساس نتايج ميانگين و انحراف معيار بدست آهده نمرة متغيرهاى اهمال كارى تحصيلى، درك مطلب و سرعت يادگيرى در گروه

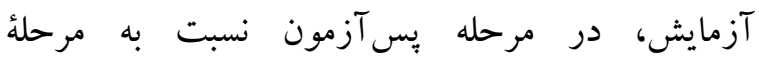

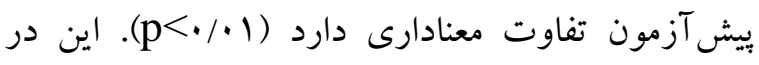

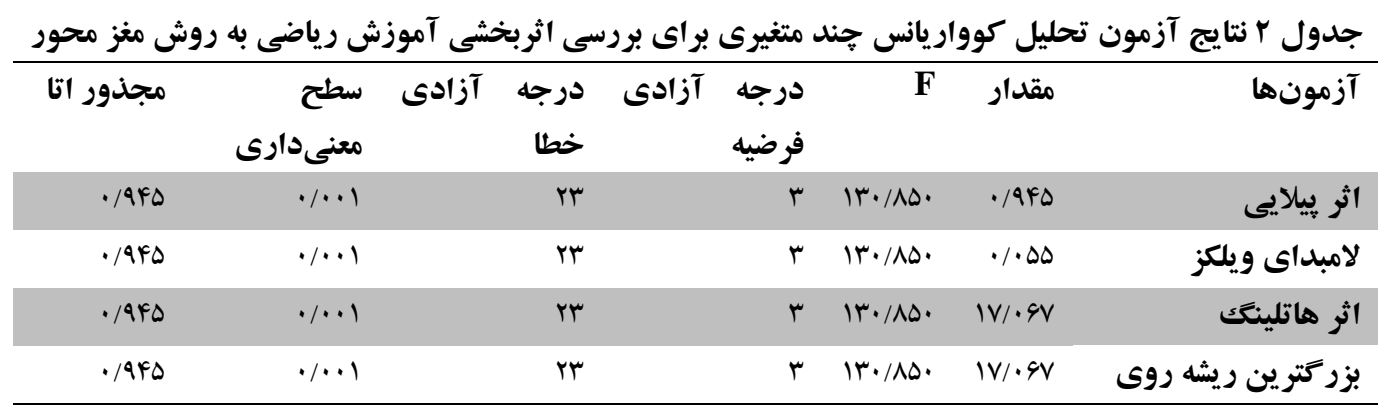

روش آموزش مغز محور يا ميزان تفاوت نمرات گروه

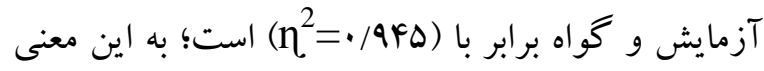

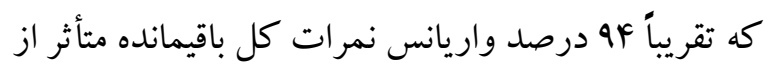
متغير مستقل است. با توجه به ميزان توان آمارى ميزان
جدول Y نشان مىدهد كه تفاوت ميانكين اهمال كارى تحصيلى، درك مطلب و سرعت ياد گيرى در دو گروه

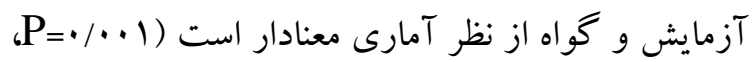

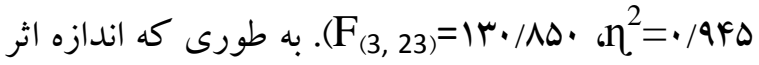


در دو گروه آزمايش و گواه از آزمون تحليل كوواريانس جندمتغيرى استفاده شده است كه نتايج در جدول بان نشان

داده شده است.
دقت اين تحليلها در كشف تفاوتهاى معنادار در سطح كامل قرار دارد و حجم نمونه براى اين آزمون كافى

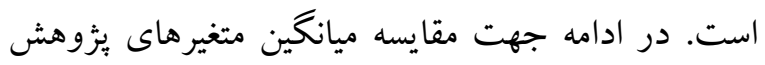

\begin{tabular}{|c|c|c|c|c|c|c|c|}
\hline اثدازه & سطح & $\mathbf{F}$ & ميانكين & درجه & مجذموع & متغير هاى وابسته & منبع \\
\hline$\cdot|M M|$ & $\cdot / \cdot 1$ & IAF/AYF & Irrq/Drq & 1 & Irrq/Drq & اهمال كارى تحصيلى & \multirow{3}{*}{ كروه } \\
\hline$\cdot$ /VGK & $\cdot / \cdot \cdot 1$ & $1 \cdot / \Delta \cdot F$ & $\vee 9 / v \cdot 1$ & 1 & $v a / v \cdot 1$ & درك مطلب & \\
\hline$\cdot / 199$ & $\cdot / \cdot 1$ & $190 / \Delta \Delta 9$ & $\Lambda 99 / r \cdot f$ & 1 & $\Lambda 99 / r \cdot F$ & سرعت ياد كيرى & \\
\hline
\end{tabular}

يزوهش حاضر با هدف بررسى اثربخشى آموزش رياضى به روش مغز محور بر اهمال كارى تحصيلى، درك مطلب و سرعت ياد كيرى دانش آموزان مبتلا به اختلال نقص توجه/ بيشفعالى انجام شد. براساس نتايج بدست آمده آموزش رياضى به روش مغز محور موجب كاهش اهمال كارى تحصيلى و افزايش دركك مطلب و سرعت ياد گيرى دانش آموزان داراى اختلال نقص توجه/ بيش فعالى مى گردد. نتايج همسو با يزّوهشهاى ايانتويى و

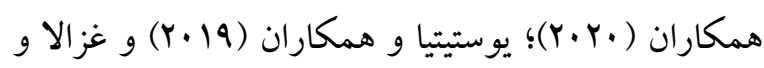
همكاران در سال (Y. IV) بود كه هر يكك به نوعى نشان دادند كه تدريس به روش مغز محور بر باد گيرى و عملكرد دانش آموزان مؤثر است. همجينين نتايج ناهمسو

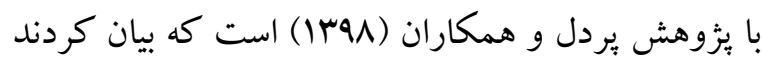
آموزش مغزمحور بر اهمال كارى تحصيلى دانش آموزان اثربخش نبوده است. اين تناقض مى تواند به دليل جامعه آمارى، ابزارهاى اندازه گيرى و يا جامعه آمارى متفاوت باشد. به طورى كه جامعه آمارى يثزوهش آن دانش آموزان عادى بودند، در صورتى كه يثروهش حاضر در بين دانش آموزان مبتلا به اختلال نقص توجه/ بيشفعالى انجام شد. علاوه بر اين، در تحقيق حاضر آموزش رياضى
نتايج جدول ب نشان مىدهد بين ميانگين نمره اهمال كارى تحصيلى، دركى مطلب و سرعت ياد گيرى دو گروه آزمايش و كنترل تفاوت معنادارى وجود دارد و تفاوت ميانكين مراحل يِيش آزمون و يس آزمون در كروه از لحاظ آمارى معنادار است و آموزش رياضى به روش مغز محور موجب كاهش اهمال كارى تحصيلى (1 (•p)

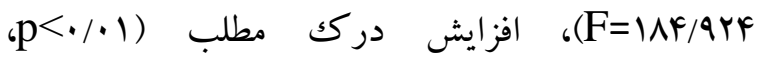
‘ $\mathrm{p}<\cdot 1 \cdot(\mathrm{F}=\Lambda \cdot / \Delta \cdot \mathrm{F}$

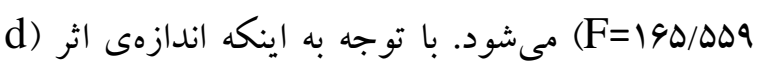
كوهن) در اين هيزوهش با استفاده از روشى كه مبتنى بر ميانگين و انحراف معيار دادههاست (تفاوت بين ميانگين هاى اولين و آخرين اندازه گيرى، تقسيم بر انحراف معيار كل)، براى d كوهن اندازهى اثر r/ • تا س/• كوجّك در نظر كرفته مىشود، اندازهاى در حدود ه/ • متوسط است و اندازهى اثر ^/ · تا بىنهايت بزرگك تلقى مىشود. در اين يزٔوهش ميزان اندازه اثر براى متغير اهمال كارى

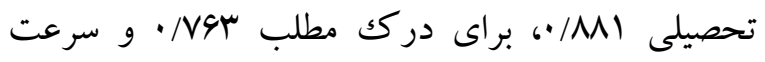
يادكيرى 199/ · بدست آمد كه نشاندهندهى اندازه اثر نزديكك به متوسط است. 
انجام مىشود. علاوه بر اين، سعى مىشود ترس ياد گيرنده كه به دليل مشكلات در حل مسئله رياضى داشته را برطرف كند و ترغيب شود تا آموختهها و دريافتهاى خود را درونى كند (ايانتويى و همكاران،

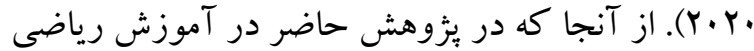
به روش مغز محور از روشهايى براى جذابيت تدريس (از جمله يوسترها، نقاشىها، فيلمها و تحرك هن هنام يادگيرى) استفاده شده كه براى دانش آموزان به ويزه دانش آموزان اختلال نقص توجه / بيش فعالى جذاب ايجاد مى كنند و با مشاركت دادن آنها در يادگيرى، ترس و استرس از مشكلات حل مسئله رياضى را درآنها كاهش داده (از طريق ياداش و تكنيككهاى آرامش دهنده) و انخيزه ياد گيرى را در آنها به وجود مى آورد؛ لذا دانش آموزان مبتل به اختلال نقص توجه/ بيش فعالى احتمالاً به

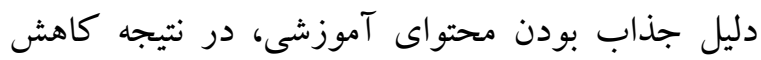

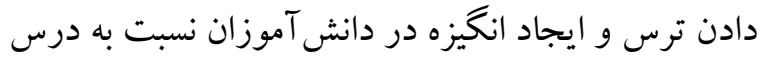
و ياد گيرى، كمتر اهمال كارى تحصيلى داشته باشند. در تبيين اثربخشى آموزش رياضى به روش مغز محور بر درك مطلب و سرعت يادگيرى نتايج همسو با يافتهاى

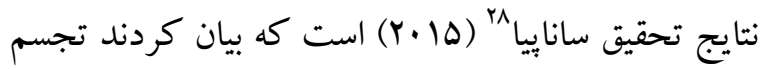
تصاوير يا گر افيك مىتواند درك دانش آموزان را توسعه دهد و دانش آموزان را قادر به برقرارى ارتباط مناسب با نتايج ياد گيرى خود كند. در همين راستا با توجه به اينكه راهبردهاى آموزشى مغز محور براى آموزش كودكان مبتلا به اختلال نقص توجه/ بيشفعالى مىتواند تفكر

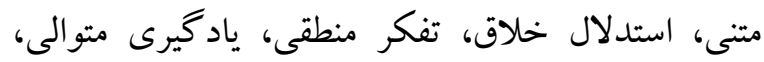
دانش شهودى و يادگيرى بصرى را بهبود دهد كه در برابر فراموشى مقاوم هستند و اين به نتايج يادگيرى

\footnotetext{
${ }^{28}$ - Sanapiah
}

مغز محور مورد تأكيد بوده است كه به دليل ناتوانى دانش آموزان به ويزه دانش آموزان مبتلا به اختلال نقص به به له توجه / بيشفعالى در حل مسائل رياضى، رفتار دانش آموز به شكل اهمال كارى در انجام تكليف داده شده، نمايان

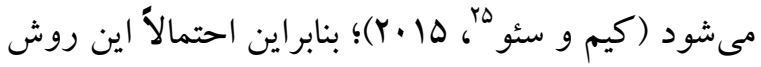
آموزشى به دليل روشهاى انخيزشى كه دارد، اهمالكارى تحصيلى دانش آموزان را كاهش دهد. براساس نتايج بدست آمده مبنى بر اثربخشى آموزش رياضى به روش مغز محور بر اهمال كارى تحصيلى نتايج همسو با يافتهاى غزالا و همكاران (Y.IV) است. در تبيين نتايج مىتوان بيان نمود مدل يادگيرى مغز محور يكك مدل يادكيرى تلاش محور است كه توانايى مغز دانش آموزان را تقويت مى كند (اورينارا، Yإب). محيط ياد گيرى ايجاد مىشود كه مهارتهاى تفكر دانشآموزان را به جالش مى كشد. محيط ياد گيرى به صورت سرگرم كننده طراحى مىشود و و يادگيرى فعال (مشاركتى) و واقعى را براى دانش آموزان ايجاد مى كند

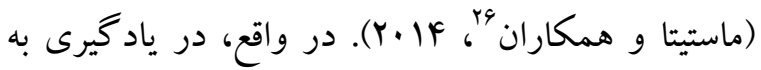
روش مغز محور با برنامهريزى دقيق، آكاهى از يافتهاى تحقيقات مغز و كمى خلاقيت، معلمان فعاليتهاى جذاب و مبتنى بر مغز را ارائه مىدهند كه كاوش و ياد گيرى را تشويق مى كند و از استانداردهاى ياد گيرى يشتيبانى مى -

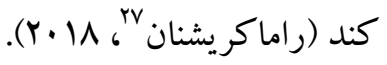
در واقع، روش ياد گيرى مبتنى بر مغز براى دانش آموزان

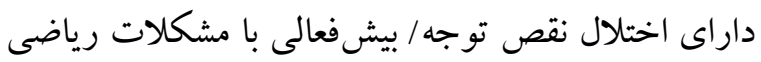
به كونهاى جذاب طراحى مى شود كه دانش آموزان عملاً در تجربههاى يادگيرى شركت داده شوند. مورد ديخر هشدار آرام است كه اين الكوى ياد گيرى براساس آن

\footnotetext{
25- Kim \& Seo

${ }^{26}$ - Mustiada

27- Ramakrishnan
} 
فعال تر مى كند و هر دو نيمكره مغز را به طور همزمان

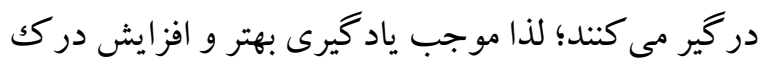
مطلب دانش آموزان مى گردد. علاوه بر اين، به دليل اينكه دركك مطالب براى دانشآموزان راحتتر شده است؛ لذا طبيعى است كه با سرعت بيشترى مطالب را ياد مى كيرند. در استفاده از اين استراتزى، معلمان نه تنها بايد محيطهاى ياد كيرى ايجاد كنند كه دانش آموزان به طور كامل در يكك تجربه آموزشى غوطهور شوند، بلكه ترس يجاد را در كود كان از بين ببرند و در عين حال محيطى بسيار جالش برانكيز را با تأكيد بر درونى سازى اطلاعات در آنها ايجاد كنند.

\section{نتيجه كيرى}

براساس نتايج بدست آمده آموزش رياضى به روش مغز

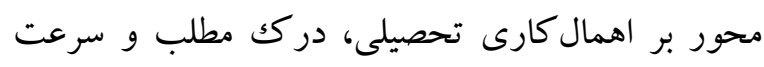

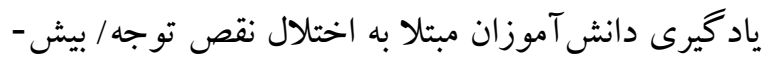

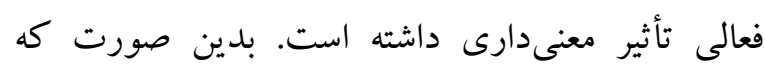
آموزش رياضى به روش مغز محور سبب كاهش اهمال كارى تحصيلى و افزايش درك مطلب و سرعت ياد كيرى دانش آموزان مبتلا به اختلال نقص توجه / بيش فعالى شد. ئزوهش حاضر با محدوديتهايى نيز مواجه بود از جمله اينكه طراحى مقطعى اين مطالعه توانايى ما در ايجاد روابط على بين متغيرهاى مطالعه را محدود كرد. از طرفى اين ئزوهش فقط در بين دانشآموزان مبتلا به

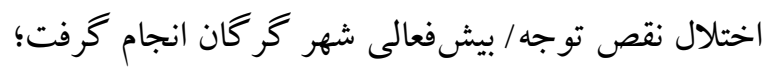

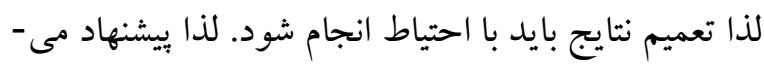
كردد اين بثزوهش در بين ساير اختلالات در شهرهاى مختلف نيز انجام شود و همجنين بيشنهاد مىشود براى بهبود بيشرفت دانش آموزان مبتلا به اختلال نقص توجه/
شناختى و هيجانى بهتر در آموزش، با توجه به ويز گكى-

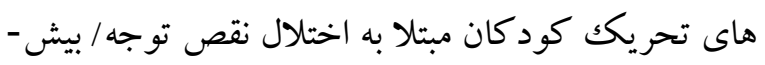
فعالى در دوره يادگيرى كمك مى كند (ايانتويى و

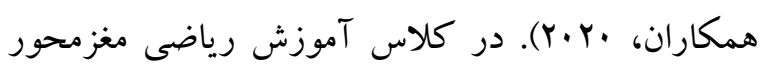
با رعايت تكنيككهاى مغز محور از جمله، با توجه به خستكى سريع دانش آموزان مبتلا به اختلال نقص توجه / بيشفعال در حين تدريس استراحت داده شد، نوشيدن آب كافى كه به آرامش فكرى دانش آموزان كمكك مى نمود و نياز مغز را برطرف مى كرد و محتواى آموزشى جذاب (با ارائه بوسترهاى جذاب) كه با توجه به اينكه دركك مفاهيم كلى از طريق تصاوير و مسئله مربوط به آن، محيط و بافت مناسبى را براى يادگيرى جزئيات به وجود

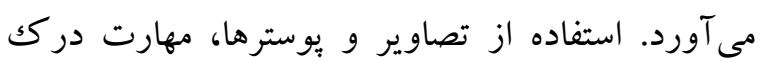
زبانى دانشآموزان را افزايش مىدهد. علاوه بر اين، معلمان از موسيقى كلاسيك و تمرينات مغزى (بازىهاى فكرى) كه سركرم كننده است نيز استفاده مى كنند تا دانش آموزان علاقهمند شوند. استفاده از موسيقى و و تمرينات مغز در يادگيرى مىتواند لذت ياد گيرى دانش -

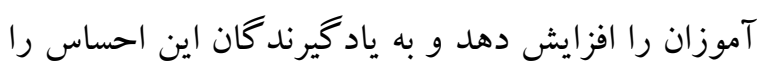
بدهد كه كلاس آنها مكانى سركرم كننده است و به ياد گيرند گان كمكك مى كند تا لحظات يا رويدادهاى مهم در يادگيرى را تشخيص دهد. با توجه به اينكه روانشناسان موسيقى ثابت كردهاند كه موسيقى عملكرد فكرى، استدلال مكانى- زمانى و ساير مهارتهاى مفيد براى يادگيرى رياضى را بهبود مىبخشد (هولمز و و

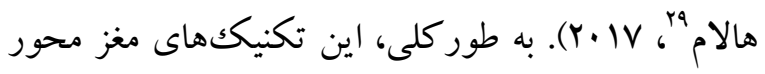
استرس و ترس از حل مسائل رياضى را كاهش، انكيزه

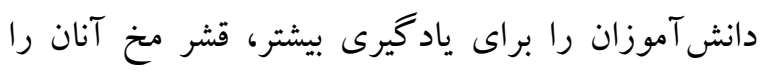

${ }^{29}$ - Holmes S \& Hallam S 
heterogeneous networks to speed up inductive semi-supervised leaming and improve automatic text categorization. KnowledgeBased Systems. 132,94-118.

Ghazala N, Riffatun NA, Hijab F. (2017). Effect of Brain-based Learning on Academic Achievement of VII Graders in Mathematics. Journal of Elementary Education. 27(2): 8597.

Handayani BS, Corebima AD. (2017). Model brain based leaming (BBL) and whole brain teaching (WBT) in learning. Intemational Journal of Science and Applied Science: Conference Series.1(2): 153-161.

Holmes S, Hallam S. (2017). The impact of participation in music on learning mathematics. London Review of Education. 15(3): 425-438.

Jensen E. (2011). Brain Based Learning Paradigm of Teaching. Jakarta: Indeks.

Jokar B, Delavarpour MA. (2007). The relationship between educational procrastination and development goals. New Educational Thoughts, 3 (3 , 4): 61-80. (In Persian)

Khan AA, Madden J. (2016). Speed Learning: Maximizing Student Leaming and Engagement in a Limited Amount of Time. I.J. Modern Education and Computer Science.7,22-30.

Khan AW. (2012). Inquiry-based teaching in mathematics classroom in a lower secondary school of Karachi, Pakistan. Intemational Journal of Academic Research in Progressive Education and Development. 1(2):1-7.

Kim KR, Seo EH. (2015). The relationship between procrastination and academic performance: A meta-analysis. Personality and Individual Differences. 82, 26-33.

Lowrie T, Jorgensen R. (2011). Gender differences in students' mathematics game. Compurers \& Education. 57(4): 2244-2248.

Maria RA, Cornoldi C. (2013). Spelling Errors in Text Copying by Children With Dyslexia and ADHD Symptoms. Journal of Learning Disabilities. 48(1): 173-183.

$$
\begin{aligned}
& \text { بيشفعالى در رياضيات، استراتزى نوآورانهاى مانند } \\
& \text { استراتزى آموزش مغزمحور بايد براى كلاس هاى عادى و } \\
& \text { كود كان داراى ناتوانى هاى ياد گيرى اتخاذ شود. } \\
& \text { سباسگز ارى } \\
& \text { مقاله حاضر بر گرفته از كار مستقل ئزوهشى دانشگاهى و و }
\end{aligned}
$$

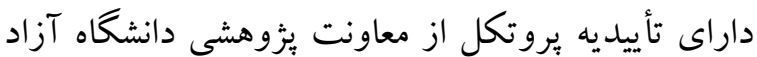

$$
\begin{aligned}
& \text { PV/IY/r/Y9AY اسلامى واحد على باد كتول به شماره } \\
& \text { مىباشد. ضمناً نويسند كان از همكارى شركت كت كنند كان } \\
& \text { كمال تشكر را دارند. }
\end{aligned}
$$

\section{References}

Agustin AR, Winarso W. (2021). Profile of Student Academic Procrastination Behavior in Problem Solving and Mathematical Digital Literacy. Jumal Didaktik Matematika. 190207.

Akbasli S, Sahin M, Yaykiran Z. (2016). The Effect of Reading Comprehension on the Performance in Science and Mathematics. Joumal of Education and Practice. 7(16): 108-121.

American Psychiatric Association. (2013). Diagnostic and statistical manual of mental disorders: DSM-5TM (5th ed.). American Psychiatric Publishing, Inc.

Arbel Y, Fialkoff C, Kemer A, Kerner M. (2020). Can Increased Recovery Rates from Coronavinus be explained by Prevalence of ADHD? An Analysis at the US Statewide Level. Joumal of Attention Disorders. 25 (14): 1-4.

Ayantoye CA, Olaoluwa SO, Caballero M, Ezell S, O'Neal Hixson K. (2020). Application of Brain-Based Teaching Strategies on Academic Performance of Children with Attention Deficit Hyperactivity Disorder (ADHD) In Mathematics. World Joumal of Educational Research. 7(1): 146-158.

Geraldeli Rossi R, Andrade Lopes AD, Oliveira Rezende S. (2017). Using bipartite 
Montgomery C. (2016). How to Improve Reading Comprehension: 8 Expert Tips." $\mathrm{H}$ ow to Improve Reading Comprehension: 8 Expert Tips. PrepScholar. Web. 10Oct.

Mustiada IGAM, Agung AAG, Antari NNM. (2014). Pengaruh model pembelajaran BBL (brain based learning) bermuatan karakter terhadap hasil belajar IPA. MIMBAR PGSD Undiksha, 2(1): 1-10.

Niermann HCM, Scheres A. (2014). The relation between procrastination and symptoms of attention-deficit hyperactivity disorder (ADHD) in undergraduate students, Int. J. Methods Psychiatr. 23(4): 411-421.

Ozturk M, Akkan Y, Kaplan A. (2019). Reading comprehension, Mathematics self-efficacy perception, and Mathematics attitude as correlates of students' non-routine Mathematics problem-solving skills in Turkey. Intemational Joumal of Mathematical Education in Science and Technology. 51(7): 1042-1058.

Pardel F, Zare Moghaddam AS, Mousavi SA, Ghorbani M. (2018). Evaluation of the effectiveness of brain-based training on academic procrastination and students' exam anxiety. Developmental Psychology, 8(6): 5851. (InPersian)

Ramakrishnan J. (2018). Brain Based Leaming Strategies. Intemational joumal of innovative research \& studies. 2(25): 235-242.

Sanapiah F. (2015). Peran Penggunaan Ilustrasi Visual dalam Meningkatkan Kemampuan Pemecahan Masalah Matematika Siswa SMP. Jumal Kependidikan. 14(3): 265-274.

Seifi S, Ebrahimi Ghavamabadi P, Farrokhi N. (2011). Investigating the effect of brain-based learning education on comprehension and learning speed of third grade elementary students. Educational innovations. 9 (34): 45-60. (In Persian)

Solomon LJ, Rothblum ED. (1984). Academic procrastination: frequency and cognitivebehavioral correlates, Joumal of Counseling Psychology. 31, 503-509. 